\title{
The Importance of Labelling Products WITH A GMO OR NON-GMO LABEL
}

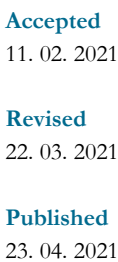

Keywords GMO

label, transparency, product control, product approval process, Regulation 1830/2003/EC

\section{KATJA MEŠKO KuRALT}

University of Maribor, Faculty of Law, Maribor, Slovenia.

E-mail: mesko.cat@gmail.com.

CORRESPONDING AUTHOR

mesko.cat@gmail.com. 


\section{$1 \quad$ General}

Presently, both the natural and social sciences are experiencing rapid innovations. Advancements that are still the subject of scientific research today, may become leading products on the market tomorrow. Some products take longer to enter the market than others, depending on several factors. These variables include the extent of the analyses and controls carried out, which are important for the free entry into the market of goods and services within a given area (e.g., within EU Member States; in the United States; worldwide, etc.).

One of the innovations that has emerged in recent decades within the territory of the EU Member States is undoubtedly the offer of products labelled without genetically modified organisms (hereinafter: GMO-free).

In general, products labelled without GMOs are those that did not contain or require GMOs in their production (i.e., from the production of raw materials for the product to the processing and production of raw materials into a product). On the other hand, there are products that do not have this label, which can result in two options. The first option is a product that does not have a GMO-free label but contains GMOs. The second option is a product that does not have a GMO-free label and does not contain GMOs, as it has not been tested by those authorized to label a product GMO-free. Regardless of labelling, products on the market can have both positive and negative effects on the individual purchaser.

\section{Introduction}

The main purpose of this paper is to define the difference between the labelling of products containing or produced from GMOs and the labelling of products with a GMO-free label. 
The contribution is based on publicly available data, i.e., on EU law and on publicly available instructions or recommendations issued in Slovenia by independent institutions, which are the Institute for Control and Certification, the University of Maribor (hereinafter: IKC UM), the international company Bureau Veritas, ${ }^{1}$ operating in Slovenia, and the Institute for Agriculture and Forestry Maribor. ${ }^{2}$

The importance of labelling GMO-free products and GMO-labelled products was analysed using a comparative research method. The analysis is based on a comparison of these two basic concepts, on a review of the legal definition of the terms, and on the control of the use of the terms.

\subsection{General terms}

A GMO is an organism whose genetic material is modified through crossbreeding or natural recombination in ways that do not occur naturally. All GMOs authorized for import into the European market are pre-screened by the European Food Safety Authority - EFSA, ${ }^{3}$ which follows professional guidelines. Moreover, the legislation of EU Member States stipulates that products produced with or from GMOs must be clearly labelled (Neuwirth \& Svetlicinii, 2015).

In the field of GMO tracking and labelling, manufacturers must comply with Regulation (EC) No 1830/2003 of the European Parliament and of the Council of 22 September 2003 concerning the traceability and labelling of genetically modified organisms and the traceability of food and feed products produced from genetically modified organisms and amending Directive 2001/18/EC (hereinafter: Regulation 1830/2003/ES). Regulation 1830/2003/ES is explicitly implemented in all EU Member States.

\footnotetext{
1 The company provides the services necessary to achieve, maintain and demonstrate compliance with the requirements of quality, environment, safety and health at work and social responsibility, including certification, e.g.: selected quality, organic production and processing, Donau soy (i.e., GMO-free soybean foods), integrated production, protected agricultural products and foodstuffs.

${ }^{2}$ It is an institute that deals with control and certification, for example: integrated and organic production and processing of agricultural products or food, also deals with the award of the label DEMETER, which represents bio-dynamic farming according to DEMETER guidelines, with control and certification of agricultural products and foods labeled Selected Quality and Vegan. The institute also performs controls of private standards e.g.: Global G.A.P.

${ }^{3}$ See section 3.2 for more information.
} 
In the field of GMO management, Regulation (EC) No 1829/2003 of the European Parliament and of the Council of 22 September 2003 on genetically modified food and feed (hereinafter: Regulation 1829/2003/EC) applies in addition to Regulation 1830/2003/ES. Regulation 1829/2003/EC's main purpose is to help ensure a high level of protection of human life and health, animal health and safety, the environment and consumer interests in relation to genetically modified food and feed, while simultaneously ensuring the effective functioning of the internal market. This Regulation also delineates both the procedure for the approval and control of GMOs and the rules for the labelling of GMOs.

The GMO label is mandatory for plant products containing more than 0.9 percent of genetically modified ingredients. However, it is not necessary to label meat, milk, eggs, fish, and other foods of animal origin which have been fed GMOs. ${ }^{4}$

Despite legal restrictions, GMO management is a topical issue in EU Member States. The advantages of the use of GMOs include the reduction of pesticide consumption and a richer yield, especially in previously unusable areas. Opponents of the use of GMOs insist that their dietary use not only reduces biodiversity and endangers the health of users but also may contain allergenic substances due to the introduction of new genes in plants (Bakshi, 2011; Krimsky, 2019).

Slovenian and EU law both stipulate that a GMO is an organism or microorganism whose genetic material is materially altered, through the processes of crossing or recombination, in manners that do not occur under natural conditions (humans are exempt). More specifically, GMOs are those organisms or micro-organisms that are obtained only by certain prescribed techniques or methods, which do not include techniques or methods of mutagenesis, i.e., a set of techniques that allow the genome of living species to be altered without the introduction of foreign DNA (EU Court of Justice 2019).

Despite the current definition, the Court of Justice ruled in Case C-528/16 that organisms created by mutagenesis techniques are also GMOs. It follows from the decision of the Court of Justice of the EU that new ways of changing organisms, ie., mutagenesis techniques or methods, does not mean that these techniques or

${ }^{4}$ Article 12 of Regulation 1829/2003/EC. 
methods should be exempted from existing EU standards on GMOs (Meško Kuralt, 2018; Wasmer 2019; EU Court of Justice 2019).

Wasmer (2019) points out that companies and research institutions dealing with GMOs face considerable legal uncertainty. Although, in principle, the uncertainties associated with the procedure for applying for a GMO release can be resolved through procedural changes, in reality these uncertainties cannot be resolved without a change in EU law relating to GMOs. However, any such solution requires the constructive cooperation of not only the European institutions but also the EU Member States. Absent changes in GMO legislation, Wasmer argues that a crisis may arise, namely that regulatory agencies will fight to enforce the GMO regime, international trade relations will be adversely affected, European agriculture will be deprived of opportunities for sustainable innovation and employment, and research and development will cease (Wasmer, 2019).

Substantial research has been performed concerning the effects of GMO (Buiatti et al. 2013; Launis 2008; Koch, 2010). Séralini, Mesnage, Clair and others are convinced, both theoretically and practically, that the use of GMOs in everyday life represents the right solution to prevent light currents in the world (Séralini et al., 2011).

Only GMO products that have been approved in the European Union can be obtained on the European market. The procedure for the authorization of (new) GMOs is performed in accordance with Regulation 1829/2003/EC 5 in Directive 2001/18/EC to the European Parliament and the Council of 12 March 2001 on the deliberate release into the environment of genetically modified organisms and repealing Council Directive 90/220/EEC (Directive 2001/18/EC). ${ }^{6}$

\footnotetext{
${ }^{5}$ In addition to the general principles set out in Regulation 178/2002/EC (i.e., risk analysis, free movement of food and feed between EU Member States, precautionary principle, consumer protection), the main objective of Regulation 1829/2003/EC is to define the basis for ensuring a high level of protection, human life and health, animal health and protection, the environment and consumer interests in relation to GM food and feed, while ensuring the effective functioning of the internal market, lay down procedures for the approval and control and determine the method of labeling GM food and feed. The procedure applies to: foodstuffs containing or consisting of GMOs; for foods produced from GMOs or containing ingredients produced from GMOs and GMOs for use in foodstuffs (Article 3 of Regulation 1829/2003/EC).

${ }^{6}$ The procedure for the administration of GMOs as or in products is defined in Part C of Directive 2001/18. The authorization procedure refers to a GMO or a combination of GMOs as a product or in products placed on the market (standard procedure).
} 
The GMO-free label provides information that the product both does not contain genetically modified organisms and that it is not produced from genetically modified organisms or with genetically modified organisms. The GMO-free label may be applied only when the products are actually inspected based on certain or standardized (commercial) criteria. Only then may such products be labelled "Pridelano/proizuedeno brez GSO - brez gensko spremenjenih organizmov «, which represents a private certification scheme in Slovenia. The certification scheme is voluntary and available to all those manufacturers / providers that want to participate in the certification process.

In Slovenia, the »Pridelano/proizvedeno brez GSO - brezgensko spremenjenih organizmov ${ }^{\mathcal{O}}$ xx certificate, while not prescribed by law, has been awarded by the IKC UM since 2011.

In order to obtain the certificate, the acquirer must demonstrate compliance not only with the requirements of general legislation in the field of GMOs, but also with any additional private (commercial) standards and requirements. There are currently 600 products on the market in Slovenia (accessed 10 August 2020), which are labelled "Pridelano/proizvedeno brez GSO - brez gensko spremenjenib organizmov ${ }^{\mathcal{Q}}$. Thus, even ordinary products are not organic.

Moreover, Slovenian legislation stipulates that only certain industrial property rights can be registered, i.e., patents, additional protection certificates, models, trademarks ${ }^{7}$ and geographical indications, which have judicial protection of rights and representation of parties in proceedings (Article 1 of the Industrial Property Act).

\footnotetext{
${ }^{7}$ Trademarks, as one of the intellectual property rights, can be acquired not only at national and regional levels, but also at EU and international levels. Registration at the national level is done at the EU's national intellectual property offices, at the regional levels in Belgium, the Netherlands, or Luxembourg at the Benelux Office for Intellectual Property (BOIP), registration at the EU level can be done in all EU Member States by registering with the European Union Intellectual Property Office (EUIPO), and international registration takes place with the World Intellectual Property Organization (WIPO). National and regional trademarks are essential for those users who do not want or need trademark protection at the EU level. EU trademarks allow users who so wish to obtain protection in all EU Member States. In any case, the EU brand can be extended to the international level, so that the trademark obtained is valid in all signatory countries to the Madrid Protocol (European Union Intellectual Property Office, 2020). If the mark is not used or is used incorrectly, the mark may also be revoked from the proprietor. In more detail, as follows from the judgment of the High Court in Ljubljana, in Cpg 479/2017 substantive objections against the registered trademark owner are admissible without the need to initiate a special procedure, i.e., by an action or by a declaration of invalidity in proceedings before a registration authority. The only difference is in the scope of protection, as success with an action for annulment under Article 114 of the Intellectual Property Act - ZIL-1 causes the termination of the registered right (first and second paragraphs of Article 72 of ZIL-1), while the enforcement of nullity objections has effect only in a concrete dispute.
} 
However, the legislation does not provide for certification of commercial designations such as e.g., "Pridelano/proizvedeno brez GSO - brez gensko spremenjenih organizmov ${ }^{\mathbb{O}} \ll$.

In Austria, the certification process for GMO-free food production is performed based on guidelines adopted by the State of Austria, i.e., Österreichische CodexRichtlinie zur Definition der Gentechnikfreien Produktion von Lebensmitteln und deren Kennzeichnung idgF, which have been in use since 1998. Given that all EU Member States follow a "farm-to-fork" strategy ${ }^{8}$, the widespread use of GMOs in Austria is not allowed. However, since 2010, an exception has been carved out in Austria for additives and technological agents used in the production of feed (e.g. amino acids, vitamins) that can be produced with the help of GMOs. In Austria (currently 10 August 2020), more than 3,500 products, including organic food, are labelled "Ohne Gentechnik hergestellt" (Arbeitsgemeinschaft für Gentechnik-frei erzeugte Lebensmittel, 2020).

In Germany, the designation "Ohne Gentechnik" is based on the guidelines laid down in national regulations, i.e., Regelung zur Kennzeichnung "Ohne Gentechnik", which have been in force since 2008. Manufacturers of GMO-free labelled products also must comply with Regulation 1830/2003, which sets forth rules on the traceability and labelling of GMOs and the traceability of food and feed produced from GMOs, such as labelling of milk, meat and eggs where animals have been fed GMO-free feed for a long time. The restriction on GMO-free labelling does not apply to additives used in feed preparation (e.g., amino acids, vitamins) and animal treatment. In the production of food, additives, vitamins and enzymes, the legislation in the field of organic farming applies, i.e., Commission Regulation (EC) No 834/2007 of 28 June 2007 on organic production and labelling of organic products and repealing Regulation (EEC) No 2454/93 2454/93 2092/91 (Regulation 834/2007/EC). Currently (accessed 10.8.2020) there are more than 8000 products in Germany labelled "Ohne Gentechnik hergestellt" (Verband Lebensmittel ohne Gentechnik, 2020; Institute for Inspection and Certification, 2020).

\footnotetext{
${ }^{8}$ The "farm to fork" strategy is at the heart of the Green Deal, which sets out how to make Europe the first climateneutral continent by 2050. The "farm to fork" strategy thus comprehensively addresses the challenges of sustainable food systems, recognizing the inextricable links between healthy people, healthy societies, and a healthy planet. It is also a central part of the Commission's agenda for dosing the United Nations Sustainable Development Goals (European Commission, 2020).
} 


\section{Labelling of the product with the GMO label and with the GMO-free label}

\subsection{Meaning of labels on the product with "GMO"}

Only GMOs approved at the European Union level can be legally traded or made available to consumer in the market. The approval process begins by filing an application for the approval of an individual GMO and continues with review by the European Food Safety Authority (EFSA). Once the EFSA has issued a favourable opinion on the risk assessment for the approval of individual GMOs, the procedure ${ }^{9}$ continues within the Standing Committee on the Food Chain and Animal Health (hereinafter: The Committee).

If no decision is taken by The Committee, or if a qualified majority is not reached, the procedure shall continue with the Board of Appeal of the Council of the EU. Three solutions are possible if the Appellate Body of the Council of the EU does not decide on the approval of GMOs. The first solution is that the European Commission approves an individual GMO based on a positive opinion of the EFSA. The second solution is that GMOs are rejected. The third solution is where the European Commission does not take a decision on GMOs.

Thus, the labelling of products that contain GMOs or produced from GMOs are of great importance in the application for approval of an individual GMO for marketing (hereinafter: application for approval of GMOs). Directive 2001/18/EC and Regulation (EC) No 1830/2003/EC ${ }^{10}$ help ensure both the traceability and labelling of GMOs at all stages of introduction of the product into the market.

In addition to both the environmental risk assessment and satisfying the conditions for placing the products on the market and producing the other required information referred to in Article 13(2) of Directive 2001/18/EC and Article 5 of Regulation $1828 / 2003 / \mathrm{EC}$, the application for GMO approval additionally must be accompanied by a labelling proposal. The proposal must satisfy the requirements

\footnotetext{
${ }^{9}$ The procedure for the authorization of new GMOs for the market is based on Regulation 1829/2003/ES and Directive 2001/18/ES.

${ }^{10}$ Introductory remarks (29) of Regulation 1829/2003/ES.
} 
laid down in Annex IV to Directive 2001/18/EC. The proposal for labelling thus already contains the proposed labelling of food and feed containing or produced from GMOs on the label or in the accompanying document. The proposed labelling must thus include the commercial name of the product, a statement: "this product contains genetically modified organisms", the name of the GMO, and the name and address of the person established in the EU responsible for placing the product on the market. All proposed labels must include information on genetic modification for the purpose of entry into one or more registries of changes in organisms that can be used to detect and identify GMO products for easier control and inspection. Information that cannot be placed, for confidentiality reasons, in the publicly accessible part of the register should be identified.

An application for the approval of an individual GMO is thus submitted for the first time to the competent authority of an EU Member State.

In Slovenia the competent authority is the Ministry of Agriculture, Forestry and Food. The competent authority shall acknowledge the date of receipt of the application and forward a summary of the application dossier both to the competent authorities of the other EU Member States and to the European Commission, which shall decide on the application. The approval procedure is continued in accordance with the rules set out in Part C of Directive 2001/18/EC.

If an individual food or feed either containing GMOs or produced from GMOs is approved, all the above in relation to labelling shall also apply. This means that a food or feed containing or produced from GMOs contains the commercial name of the product, a statement: "this product contains genetically modified organisms", the name of the GMO, the name and address of the person established in the EU responsible for placing the product on the market and directions on how to obtain information in the publicly accessible part of the register. 


\subsection{Meaning of the label on the product "GMO-free"}

To obtain the certificate and the mark "»Pridelano/proizvedeno brez GSO - brez gensko spremenjenih organizmov ${ }^{\mathbb{Q}}$ « which is awarded by IKC UM, an application containing certain conditions defined by the rules of IKC UM is also required. In particular, a customer applying for the certification procedure for the label ${ }^{11}$ must not only be entered in the register of economic operators but must also have his activity registered and approved by the competent authority.

At the suggestion of the customer applying for the certification process, IKC UM may also inspect the farm, production plant, feed mixer, warehouse, or shop. If a customer wishes to obtain a certificate granted by IKC UM, he must first register with IKC UM. The customer must include with the application a signed contract between the customer applying for the certification process and IKC UM. IKC UM then performs a customer check designed to assesses the level of risk, which is divided into four stages (level 0 - no risk, level 1 - low level of risk; the plant contains GMOs but there is no possibility of contamination, level 2 - medium level of risk; there is a possibility of contamination however, the various measures implemented by the customer prevent level 3 - high level of risk; there is a high level of risk of contamination with GMOs and certification according to the standard "Pridelano/proizvedeno brez GSO - brezgensko spremenjenih organizmov ${ }^{\circledR} "$ " is not possible).

If the customer meets all the requirements of the documents specified in the rules of IKC UM and the products pass the inspection, the customer is issued a certificate and allowed to use the above mark. For the labelling of foodstuffs, the customer has the right to use this label by obtaining such a certificate. Certified feed can also be described as "Primerno za proizvodnjo zivil po zasebnem standardu Pridelano/proizvedeno brez. GSO - brez gensko spremenjenih organizmov ". To the extent that they comply with the rules set by the IKC UM, the owners of agricultural holdings or processing plants also have the right to use this mark. The same is true with respect to farms that have certified organic crops and food. The certificate according to the standard "Pridelano/proizvedeno brez GSO - brez, gensko spremenjenih organizmov ${ }^{\mathcal{Q}}$, issued by IKC $\mathrm{UM}$, can also be permanently or temporarily revoked under certain conditions, and the scope of the certificate can also be expanded and reduced. The issuer of the

\footnotetext{
${ }^{11}$ It is a produced without GMOs - without genetically modified organisms.
} 
certificate may also decide to issue only a partial certificate or to refuse to issue a certificate. Both possibilities are specified in the Rules of the certification procedure (Institute for Control and Certification UM, 2020).

Another certificate provider, Bureau Veritas, is involved in the certification of the Donau Soja brand. This brand represents a quality scheme for food produced from soybeans and feed. The soybeans are grown only in the Danube basin. The scheme encourages and promotes the production and sale of GMO-free food and feed. The primary goal of this scheme is to increase soybean production in Europe and thus reduce the dependence of EU Member States on protein crop imports, while simultaneously offering a certified raw material that appears on the European market under a single brand. The Donau Soybean brand, which contains pre-prescribed standards, is intended for soybean growers, food producers (e.g., foodstuffs of animal and plant origin where soy is used as a basic raw material or as one of the ingredients), feed manufacturers and soybean traders. Bureau Veritas is a control body authorized by the international initiative Donau Soy to verify compliance with the requirements of the Donau Soy standard for the production and manufacture of soybean foods (Bureau Veritas, 2021).

\section{General information on the control over the scope of GMO use in Slovenia}

Because Slovenia is one of the EU Member States, the producer of the GMO product must comply with several regulations, including Regulation 1829/2003/EC, Regulation 1830/2003/EC and Regulation implementing Regulation (EC) on genetically modified food and feed and Regulation (EC) on the traceability and labelling of genetically modified organisms, and Directive 2001/18/EC.

The Inspectorate of the Republic of Slovenia for Agriculture, Forestry, Hunting and Fisheries - IRSKGLR, which is a body within the Ministry of Agriculture, Forestry and Food, has official supervision over the implementation of the above-mentioned regulations. This inspectorate performs official controls in the segment relating to food of animal origin. IKGLR also controls the production of genetically modified plants, which is defined in more detail in the Act on Co-existence of Genetically Modified Plants with Other Agricultural Plants (hereinafter: ZSGSROKR). 
Supervision of food and feed containing or produced from GMOs is carried out by the Administration for Food Safety, Veterinary Sector and Plant Protection (hereinafter: UVHVVR), which is also a body within the Ministry of Agriculture, Forestry and Food. In accordance with the Management of Genetically Modified Organisms Act (hereinafter: ZRGSO), control over GMOs is performed by the Inspectorate of the Republic of Slovenia for the Environment and Spatial Planning (hereinafter: IRSOP), which is a body within the Ministry of the Environment and Spatial Planning.

The Health Inspectorate of the Republic of Slovenia (hereinafter: ZIRS) is also a body within the Ministry of Health.

In connection with the provisions of the ZSGSROKR, acts that are contrary to the regulations are also punishable by a pre-determined sanction (for example: undeclared production of a genetically modified plant (hereinafter: GMP), GMP production contrary to a production declaration or annual production plan located in GMP production areas, non-implementation of coexistence measures and noncompliance with GMP producers).

According to the ZRGSO, the production of illegal GMPs is also punishable.

The Nature Conservation Act (hereinafter: ZON) prohibits the cultivation of GMOs if the introduction / release of GMOs is prohibited.

\subsection{Review of the work of supervisory bodies that control the scope of GMO use in Slovenia}

In Slovenia, the agricultural inspectorate, IRSKGLR, is responsible for the scope of GMOs. The 2017 IRSKGLR report states that the presence of GMOs was detected in tested products based on the analysis of green parts of maize, oilseed rape and soybean plants in fields or seeds on farms. Samples taken at harvest, included nine samples of maize, two samples of oilseed rape and five samples of soybean. Based on the opinion of the analysis assessor from the National Institute of Biology, all samples were consistent. Thus, this competent inspection did not expose any irregularities with respect to this area of work and accordingly, there was no need to impose any penalties. Linked to the 2016 report, it also appears that the Agricultural 
Inspectorate inspected for the presence of GMOs in the green parts of maize, oilseed rape and soybean plants in fields or seeds on farms. Samples were taken partly before sowing and partly from seed residues after sowing. Eleven samples of maize, one sample of oilseed rape and two samples of soybean were taken. Based on the opinion of the National Institute of Biology analysis analyst, all samples were consistent. In 2015, the green parts of maize, oilseed rape and soybean plants in fields or seeds on agricultural holdings were analysed for the presence of GMOs. The Agricultural Inspectorate thus sampled conventional seeds for possible random or unintentional presence of genetic changes. Seven samples of maize, two samples of oilseed rape and one sample of soybean were taken on larger farms. All samples were negative for the presence of GMOs. Based on the report, in November 2015 the Inspectorate for Agriculture, Forestry, Hunting and Fisheries also supervised the sale of rapeseed seeds of the RAGT seed company. The seeds of the hybrid oilseed rape HRC 918 were reported to contain GMOs, OXY 235 seeds. Consequently, it was established that the said GMO seeds may not be sold in Slovenia. Rather, in Slovenia, the only seeds on the authorized variety list are the BONANZA F1 oilseed rape seeds, RAGT seed plant, supplier R.A.G.T. SAATEN OSTERREICH.

The IRSOP Work Report shows that in 2017, inspectors performed 119 regular, 48 extraordinary and 22 other inspections in the field of GMO control. They issued 53 warnings and issued six inspection decisions to remedy the non-compliance. No misdemeanour proceedings were instituted. IRSOP receives very few reports in this area of work. Most of the work is carried out based on a program of supervision of persons liable for work in closed systems. The most common shortcomings identified in the control of GMO handling in closed systems are related to record keeping (e.g., keeping records of supervision over the implementation of containment measures, keeping records of training, preparation of written instructions for external cleaning staff, regular review of emergency plans or emergency) and the failure to implement prescribed containment measures (ensuring control of vectors, i.e., barred windows in the laboratory). IRSOP receives notifications through the "EU alert" system, through which Member States and the European Commission are informed about unauthorized GMOs found on the EU market. One such example was the genetically modified petunias in 2017. Based on information obtained from the European Commission on suspected sales of genetically modified orange petunias on the EU market, and in some Slovenian horticulture, IRSOP introduced control procedures carried out on fourteen 
taxpayers (i.e., horticulture). In the proceedings, it was determined that orange petunias with commercial names, as stated in the European Commission's notification, were also sold in horticulture. Horticulture in Slovenia purchased these petunias from at least three wholesalers from EU Member States. Individual horticulturists reported during the inspection that they had been notified in advance of the suspected presence of GMOs in orange petunias and accordingly had withdrawn them from sale and destroyed them. Thus, during the inspection, they were no longer in stock, could no longer be purchased and were not available for inspection. Individual horticulturalists stated, however, that they had already sold petunia seedlings by the time of the inspection. One horticulture stated he had withdrawn and destroyed the rest of the seedlings while one horticulture reported that he had used the rest for its own use. In view of the above findings, there was no reason for further inspection procedures or for the imposition of inspection measures and so the proceedings against the taxpayers were terminated.

In 2016, the IRSOP conducted eight regular inspections of GMO handling in closed systems involving either the first or second safety class. ${ }^{12}$ In relation to the identified shortcomings, a regulatory decision was issued (i.e., to ensure the implementation of the containment measure - work surfaces that can be cleaned), or warnings were issued on the minutes. The taxpayers involved in these inspections complied with the regulatory decisions within the agreed deadlines. The most common shortcomings identified as a result of these inspections were related to record keeping (records pertaining to supervision of detention measures, of training, of preparation of written instructions for external staff performing cleaning, regular checking of accident or emergency plans) and deficient implementation of prescribed detention measures. The taxpayers rectified the deficiencies in the minutes after the warnings were issued.

\footnotetext{
${ }^{12}$ Josef Stefan Institute, UL, Faculty of Veterinary Medicine - Mestni log, Faculty of Veterinary Medicine - Gerbičeva ulica, University of Ljubljana, Faculty of Chemistry and Chemical Technology, University of Ljubljana, Bio Technical Faculty, Department of Biology, UL, Bio Technical Faculty, Department of Agronomy, UL, Faculty of Electrical Engineering, University of Ljubljana, Faculty of Medicine - Institute of Biochemistry.
} 
In 2015, the IRSOP conducted seven regular inspections of GMO handling in closed systems involving either the first or second safety class. ${ }^{13}$ The inspections revealed minor deficiencies, which were rectified by the taxpayers within a certain deadline. The most common deficiencies were related to the implementation of prescribed containment measures (i.e., minor damage to soil and laboratory equipment, missing biohazard label) and deficiencies in record keeping.

\subsection{Control over the labelling of GMO-free products in Slovenia}

IKC UM, as the owner of the certificate with the »Pridelano/proizvedeno brez GSO brez.gensko spremenjenib organizmov « (C) supervises the use of the certificate and label at points of sale, on websites and in the advertising and promotion of agricultural products or food/products or activities. Supervision is carried out as part of regular and additional controls. When supervising, IKC UM refers to its internal instructions. ${ }^{14}$

In general, when IKC UM finds a discrepancy in the use of a valid certificate with the client, the client is notified of the irregularities or non-conformities and is given a deadline for taking appropriate action to bring these irregularities or shortcomings into conformance. However, where the supervisory authority finds nonconformities in the context of an invalid certificate, it shall invite the client to provide a valid certificate. If this certificate is not available, the non-compliance shall be determined in accordance with the IKC UM operating instructions.

If an infringement has been confirmed in the extraction process, IKC UM has several options. IKC UM may thus issue a certificate, may issue a certificate in part or provisionally approve it, or may not issue a certificate at all. However, when IKC UM finds non-compliance with a contractor who does not have a valid certificate (e.g.,: certification process is not completed or in progress, certificate revocation, certificate revocation, suspension) but a valid contract, IKC UM terminates the contract and requests references to immediate revocation IKC UM certificate for use in promotional or marketing purposes. When IKC UM finds non-compliance

\footnotetext{
${ }^{13}$ Lek d. d., Acies bio d.o.o., Institute of Chemistry Ljubljana, Faculty of Medicine Maribor, Faculty of Medicine Ljubljana, Institute of Pathology and Institute of Pharmacology, National Laboratory for Health, Environment and Food Maribor.

${ }^{14}$ More details in the Rules of the certification procedure, the Rules for the use of the IKC UM certificate and mark and the Rules for the use of certificates and marks of private certification schemes, IKC UM.
} 
with the Contractor, it terminates the contractual relationship and invites the Contractor in writing to immediately terminate the reference to the certificate and the IKC UM mark used for promotional or marketing purposes.

Regarding the correct use of the certificate and the mark, third parties also can report violations to IKC UM. Alleged violations often consist of such matters as the unjustified reference to the certificate or unauthorized use of the mark for promotional and marketing purposes of the infringer. In case of identified violations, IKC UM notifies the violator in writing to immediately stop referring to the certificate and using the mark.

\subsection{Monitoring the use of GMO labelling in EU Member States}

The labelling of food and feed containing or produced from GMOs is mandatory in EU Member States. The law stipulates that products produced from GMOs must be labelled with the words "genetically modified" or "produced from genetically modified (name of the organism)". The law also stipulates that operators must take steps to ensure the traceability of individual GMO labels through all phases of placing their products on the market (Ministry of Agriculture, Forestry and Food, 2020). ${ }^{15}$

It is generally accepted that GMO control authorities are responsible for taking action to prevent the spread of infections caused or likely to be caused by GMOs, to control GMO intake values where permitted, and to advise companies as well as individuals on the appropriate use of products that contain GMOs. GMO control authorities are autonomous bodies that conduct their work independently. This is critically important, as their work and decisions are not or should not be influenced either by politicians or private sector companies dealing with GMOs. In the territory of the EU Member States the following control authorities have the broad task of regulating the field of GMOs.

\footnotetext{
${ }^{15}$ It is a collection of internationally recognized standards and practices, instructions and other recommendations related to food, their production and safety standards. The Codex Alimentarius Commission, with a view to protecting human health, protecting the interests of consumers and promoting good business practice in international trade has adopted international standards for foodstuffs. The Codex Alimentarius Commission, established in 1963, is a joint body of the FAO and the WHO. The signatories of the Codex Alimentarius are countries that are otherwise members of the FAO and/or WHO. Slovenia has been a member since 1993 (World Health Organization, 2020).
} 
The European Food Safety Authority (EFSA), established in 2002 in Parma, Italy, is an independent, scientific entity that is equipped to provide advice and information on the risks associated with the food chain. EFSA was established as part of a program designed not only to improve food safety in the EU but also to ensure a high level of consumer protection and restore and maintain confidence in the EU's food supply. Good cooperation is essential for the effective management of such an expansive area of food and feed safety, which is why the EFSA Management Board has adopted a cooperation strategy between the EU Member States and EFSA. The strategy requires each EU Member State to designate an information point that will be responsible both for organizing and coordinating work in the field of risk assessment at the national level and for the preparation and implementation of the EFSA work program (National Institute of Public Health, 2020).

In Slovenia, an agreement on the establishment of an information point for EFSA was signed by the Ministry of Agriculture, Forestry and Food. In Slovenia, within the adopted strategy, many different scientific networks (members) are included. These members are from different fields of work (e.g., members of the National Institute of Public Health are members of the scientific network for microbiological risk assessment, scientific network for risk assessment related to nanotechnology, scientific networks for food contact materials, scientific networks for data on food intake, scientific communication networks and scientific networks for novel foods) (National Institute of Public Health, 2020).

EFSA's main task is to provide independent scientific advice on not only existing but also emerging food risks. In this way, EFSA contributes to the development of European legislation in the field of food safety, contributes to changes in rules and policies, and helps protect consumers from risks associated with the food chain. These same considerations also apply to products labelled with GMOs. Accordingly, EFSA is also responsible for food and feed safety, nutrition, animal health and protection, and plant health and protection. 
EFSA also collects scientific data and gathers expertise; provides independent, upto-date scientific advice on food safety; informs the public about its scientific work; and works with EU Member States, international organizations, and other stakeholders, to help develop and build confidence in EU food safety (European Food Safety Authority, 2020).

Hilbeck, Meyer, Wynne et al. (2020) are convinced that EFSA is not performing its legally-required tasks. They believe that EFSA's predominant approach to assessing GM crops and food is based on what is called 'comparative safety assessment'. These comparisons require an overview of the sets of molecular, chemical, and phenotypic data from the GMP rather than the GMOs-(many of which can only be remotely related to the GM variety). According to the authors, these data are not appropriate for predicting adverse biological, toxicological, and ecological effects. Moreover, the authors add that EFSA cites overly optimistic conclusions based on insufficient data from insufficient studies in its comparative environmental risk assessments. According to the authors, the responsibility for choosing how EFSA implements its scientific approach should lie with the risk manager. The authors add that such responsibility could be transferred to the European Commission if it implemented the explicit commitments it had made under the Codex Alimentarius for years.

Deluyker (2017), however, is of the opinion that EFSA fully justifies its existence and that it operates in full compliance with legal norms. He adds that there are scientific experts at EFSA who rely upon existing evidence and agreed assessment methods, the results of which are made public. He also argues that the work carried out under EFSA is of this quality, exhibits consistency, is independent, and reflects impartiality, as well as transparency and openness. For successful operation, it is important to constantly monitor science, follow evolving trends (e.g., nature is increasingly burdened by external influences, so it is necessary to adapt in order to find good alternative solutions, especially in the field of human and animal nutrition, which encourages sustainable development).

As stated by Chvátalová (2019), EFSA is an independent institution that performs its work in a completely professional, precise, and independent manner. Chvátalová examined part of the environmental risk assessment resulting from the EFSA scientific opinion, in particular the effects of MON810 maize on bees and earthworms. The EFSA scientific document is the basis for the decision to extend 
the authorization for the legal cultivation of MON810 maize. His research indicates (Chvátalová, 2019) that "the scientific studies cited in the EFSA Opinion in the sections concerning the possible impacts of GM maize on honeybees and earthworms stem predominantly from reliable sources in terms of authorship, financial support, and status of the study. However, the reliability of the studies varies significantly concerning the ecological relevance of the experiments. Moreover, the body of referenced evidence is insufficient to draw conclusions on risk. Relevantly, several types of shortcomings in the use of scientific information in the risk assessment were identified as prevalent, namely: EFS A omits relevant available studies, selectively cites information, misquotes studies, fails to acknowledge uncertainties, fails to call for further research where needed, and fails to critically interpret studies and their findings."

The European Medicines Agency (EMA) is a decentralized EU agency responsible for the scientific evaluation, control and monitoring of the safety of medicines in the EU. Founded in 1995, it is headquartered in Amsterdam. The EMA is a network organization comprised of thousands of experts from all over Europe. These experts carry out the work of the seven EMA Scientific Committees (i.e., the Committee for Medicinal Products for Human Use, the Committee for Veterinary Use, the Committee for Orphan Medicinal Products, the Committee for Advanced Therapies, etc.). The main tasks of the EMA are:

- encourages the development of medicines and their availability,

- evaluates applications for marketing authorizations,

- monitors the safety of medicines throughout their life cycle, and

- provides information to healthcare professionals and patients (European Medicines Agency, 2016).

One of the EMA's roles is to link regulatory authorities and the pharmaceutical industry in order to discuss the scientific and technical aspects of the registration and maintenance of medicines. Coordination between authorities is achieved through the development of guidelines generated by The International Council for the Harmonization of Technical Requirements for Pharmaceuticals for Human Use $(\mathrm{ICH})$. The key to satisfactory performance is the commitment on the part of the regulators to implement (enforce) these guidelines. Moreover, the ICH guidelines (i.e., around 60 guidelines) are increasingly recognized as international standards (European Commission, 2020b). 
EMA works closely with EU Member States and seeks to establish strong links with partner organizations around the world in order to, among other things, promote the timely exchange of regulatory information and expertise and to develop best practices in the field of drug regulation worldwide. The EMA is thus involved in a wide array of endeavours, such as investigating and examining the efficacy of products intended for markets outside the EU (e.g., products examined in accordance with the procedure laid down in Article 58 of Regulation (EC) No 726/2004 of the European Parliament and of the Council of 31 March 2004 Authorization and supervision of medicinal products for human and veterinary use and establishing a European Medicines Agency (Regulation 726/2004/EC), the quality of medicinal products and the development of international non-proprietary names.

For EU Member States, one of the most important forums is the multilateral international cooperation of the ICH, which links regulatory authorities for the medicines and pharmaceutical industries from Europe, Japan, and the United States. The ICH Council focuses on coordination in the areas of safety, quality, and efficacy, which are the main criteria for approving new medicines. The International Veterinary Conference for Coordination is also a forum for medicines designed for veterinary use, and performs the same role as the ICH performs for human health (European Medicines Agency, 2020).

In the EU Member States, Regulation 726/2004/EC, which deals primarily with marketing authorization procedures and the supervision of medicinal products for human and veterinary use, applies in the field of medicinal products. Generally, medicinal products containing or consisting of GMOs may be subject to environmental risks. Accordingly, a specific environmental risk assessment procedure must be carried out for those medicinal products. However, the COVID19 outbreak changed circumstances. Therefore, a (provisional) regulation has been adopted, namely, Regulation (EU) 2020/1043 of the European Parliament and of the Council of 15 July 2020 on the conduct of clinical trials with and supply of medicinal products for human use containing or consisting of genetically modified organisms intended to treat or prevent coronavirus disease (COVID-19) (hereinafter: Regulation 2020/1043/EC). This Regulation, in order to search for a vaccine against coronavirus disease, allows for all activities related to the conduct of clinical trials to develop a human medicine for the treatment or prevention of 
COVID-19. It also provides that such products (materials) containing or consisting of GMOs do not require a prior environmental risk assessment or approval (Article 2 of Regulation 2020/1043/EC). Obviously, the world currently is confronted with an emergency in which the use of GMOs plays an important role, not only for science but primarily for global public health. The importance of the use of GMOs in the world is underscored through such extraordinary events. Therefore, even the many detractors of GMOs must consider the potentially significant role they might play in the field of virology in the face of a pandemic taking the lives of millions.

The European Chemicals Agency (ECHA) is dedicated to the safe use of chemicals. Established in 2007, and based in Helsinki, Finland, the ECHA is focused on European chemicals legislation that not only protects human health and the environment but also promotes innovation and competitiveness. The ECHA performs the following primary tasks:

- assisting companies to help ensure compliance with the requirements of EU chemicals and biocides legislation;

- working with international organizations and stakeholders to promote the safe use of chemicals;

- developing and promoting a unique, free-of-charge database containing information on chemicals and their safe use;

- working with the Commission and EU Member States on the identification of chemicals of concern and deciding at the EU level on risk management measures, and;

- promoting innovation in the chemical industry by removing substances of concern and replacing them with safer substitutes (European Commission, 2020b).

The ECHA thus regulates chemicals on the EU market. It both processes documentation regarding chemicals prepared by manufacturers and verifies their compliance with legal requirements. ECHA, together with EU Member States, focuses on the most hazardous substances in cases where additional risk management is needed to protect both the public and the environment. With the help of applicable legislation in the field of chemicals, the ECHA provides numerous benefits, in the realm of the adoption of measures designed to: 
- reduce exposure to hazardous chemicals;

- better inform the public both on the hazards associated with chemicals and their safe use;

- assist the public with complying with regulatory requirements (e.g., innovative companies can take advantage of the phasing-out requirement), and;

- informing the public on the safe handling of hazardous chemicals.

According to the British researcher Petruzzello (2020), the great advantage of chemicals ${ }^{16}$ over mechanical weed control is their ease of use. This is especially true for cereal fields, pastures, forests, and other cases where airplanes can be used to broadcast the chemicals used to control weeds. Millions of hectares are cultivated aerially each year, and modern herbicide-type tillage equipment makes weed control increasingly convenient (e.g., sprayers, tillage equipment and herbicide spreaders allow farmers to cultivate the soil faster; machines that simultaneously build flower beds, plant seeds, spray with insecticides and include fertilizers and herbicides in one process).

However, some agricultural plants, known as herbicide-resistant crops, have been genetically engineered to resist certain chemical herbicides, in particular glyphosate. These GMOs have been available since the mid-1980s and allow for effective chemical weed control, as only plants, i.e., herbicide-resistant crops survive in fields

\footnotetext{
${ }^{16}$ Chemical weed control has been used for an exceptionally long time. Sea salt, industrial by-products and oils were used first. Selective control of broadleaf weeds in cereal fields was discovered in France in the late 1990s and this practice soon spread throughout Europe. Sulphates and nitrates of copper and iron were used, and sulfuric acid proved to be even more effective. The application was by spraying. Soon, sodium acetate became popular as a spray as a soil sterilizer. Thousands of kilometers of railways and sugar cane and rubber plantations in the tropics have used hazardous substances in exceptional quantities, often poisoning animals and occasionally humans. Diesel oil as a general herbicide and sodium dinitrokrezilat (Sinox) as a selective plant-killing agent were introduced in the first three decades of the 20th century. Sinox, the first major organic chemical herbicide, was developed in France in 1896. In the late $1940 \mathrm{~s}$, new herbicides were developed from research during World War II, and the era of miraculous weed killers began. In 20 years, more than 100 new chemicals have been synthesized, developed and used. Chemical weed control has replaced plant disease and insect control in economic terms. The year 1945 marked a new period of chemical weed control. Then 2,4-D (2,4-dichlorophenoxyacetic acid), 2,4,5-T (2,4,5trichlorophenoxyacetic acid) and IPC (isopropyl-N-phenylcarbamate) were introduced, the first two selective as foliar sprays against broadleaf weeds, the third selective against grass species when applied through the soil. The new herbicides were revolutionary, as their high toxicity allowed for effective weed control at doses of one to two pounds per hectare. This was in contrast to carbon bisulfide, borax, and arsenic trioxide, which were needed at rates of up to one tonne per hectare, and sodium chlorate, required at rates of about 100 pounds per hectare. However, some of these early herbicides, including 2,4,5-T, were later assessed as hazardous to humans and the environment and discontinued in many countries. Effective herbicides continue to be developed, and some, such as glyphosate, are widely used worldwide (Petruzzello, 2020).
} 
treated with the appropriate herbicide. However, as Petruzzello (2020) points out, these crops only serve to encourage increased application of chemicals to the soil, a practice which remains particularly controversial, especially in terms of both its environmental impact and general safety.

The field of GMOs and chemicals is a particularly important area, especially in terms of its potentially detrimental consequences for humans and the environment. On the other hand, there are obvious benefits as well. For example, it both perpetuates and enhances the existence of certain crops, as their adaptability to weather conditions allows growth and development. To minimize the negative long-term effects of the use of chemicals, while at the same time maximizing their advantages, in my opinion it is necessary to constantly monitor and control this area, both professionally and secularly (i.e., objectively reporting the results and outcomes of the effects of chemicals containing GMOs or GMO products).

The European Centre for Disease Prevention and Control (ECDC), founded in 2005, and based in Stockholm, Sweden, seeks to improve the protection of the population of EU Member States against communicable diseases (e.g., helping EU Member States and monitoring the spread of COVID-19 disease across the EU).

The ECDC is primarily tasked with analysing and interpreting data from the EU Member States concerning 52 communicable diseases and conditions. Its analysis is performed utilizing The European Surveillance System (TESSy). ${ }^{17}$ The ECDC provides scientific advice to EU Member States and EU institutions. It also works on the early detection of new communicable diseases and analysis of new threats to EU countries. The ECDC also coordinates the European Training Program in Interventional Epidemiology and the European Training Program in Microbiology in Public Health. In case of disease outbreak, ${ }^{18}$ the ECDC aids EU Member States (European Commission, 2020c). The work of the ECDC is based on the knowledge of professional staff, trans-European disease networks and national public health authorities (European Center for Disease Prevention and Control, 2015).

\footnotetext{
${ }^{17}$ It is a computerized system that systematically provides the collection analyzed in the dissemination of data on communicable disease control in Europe.

${ }^{18}$ For example, in the event of an outbreak of Covid-19, the ECDC has issued long-term care guidelines for EU Member States, targeting both staff and residents in long-term care facilities (European Commission, 2020c).
} 
The ECDC operates three important systems covering different areas of disease management, namely: hazard detection and warning, epidemic notification, and disease monitoring. The ECDC works closely with other EU agencies and non-EU organizations, i.e., the European Medicines Agency, the European Food Safety Authority, and WHO. The ECDC's work benefits the various EU public health stakeholders, including in particular (European Centre for Disease Prevention and Control, 2015):

- national and sub-national public health authorities in the EU/EEA;

- EU institutions;

- other European policy makers, and;

- public health experts, researchers, international organizations, and national authorities outside Europe.

Having the technical ability and knowledge to be able to measure the number of GMOs in food has proven to be especially useful in the field of disease prevention and treatment. The measurements used are similar to those used by scientists to count and treat therapeutic viruses with a single dose of Zolgensma. ${ }^{19}$ Zolgensma is a gene therapy treatment used for babies suffering from spinal muscular atrophy and who are less than two years old. The drug was approved by the FDA in America in May 2019. Spinal muscular atrophy (SMA) is a severe neuromuscular disease characterized by loss of motor neurons, leading to progressive muscle weakness and paralysis (Naso et al., 2017).

Modern drugs such as Zolgensma used in gene therapy make it possible to correct defects in human genes and thus treat dreadful genetic diseases. Unlike traditional medicines, these drugs do not contain chemical compounds, but instead viruses that serve as "delivery vehicles" for healthy replacement genes. Adeno-associated virus (AAV) is a non-enveloped virus that can be engineered to deliver DNA to target cells, and has attracted a significant amount of attention in the field, especially in clinical-stage experimental therapeutic strategies. The genetically modified adenoassociated virus is important for use in gene therapy. Their different strains deliver

\footnotetext{
${ }^{19}$ This medicine has not yet been authorized in the EU, but the Committee for Medicinal Products for Human Use, which operates within the EMA in May 2020, recommended that Zolgensma be granted a conditional marketing authorization.
} 
packets to different body tissues, on the target cells. By selecting an individual strain, the drug can be delivered to a specific selected tissue. The AAV virus efficiently transfers healthy genes to human cells, where it replaces inactive genes that cause disease (Naso et al., 2017).

SMA causes a mutation in the survival motor neuron 1 gene (hereinafter: SMN1), which requires motor neurons - the nerve cells that control muscle contraction - to survive the SMN protein. The mutation prevents this gene from producing functional proteins. Zolgensma is designed to replicate working copies of the SMN1 gene in motor neurons. Zolgensma thus comprises a shell (capsid) of a genetically modified AAV virus that contains a normal copy of the SMN1 gene for targeting motor neurons. When the SMN1 gene (called a transgene because it comes from an external source) reaches a patient's cells, it allows those cells to produce SMN proteins. The SMN1 transgene in Zolgensmi consists of double-stranded DNA, which means that it has the same shape as natural genes and can be activated more quickly, making therapy faster and more effective. Zolgensma also includes genetic instructions for activating the transgene so that SMN protein production is continuous and sustained (Bio News Serices, 2021).

Scientific methods are still urgently needed to develop revolutionary medicines. The method of counting GMOs is thus important for the development of Zolgensma. The National Institute of Biology (hereinafter: NIB) has developed experience in this counting method. NBI is thus collaborating with the biotechnology company AveXis from the Novartis Group in further research.

The European Environment Agency (EEA) was established by Regulation 1210/90/EEC and is based in Copenhagen, Denmark. Its main task is to provide targeted and reliable environmental information. Additionally, the EEA assists EU Member States not only in taking decisions on improving the environment and integrating environmental aspects into economic policies but also achieving sustainable development. 
Regulation 1210/90/EEC also established the European Environment Information and Observation Network ${ }^{20}$ (EIONET). Currently, 33 countries $^{21}$ and six observer countries participate in this network. ${ }^{22}$

The EEA has also established European thematic centres to manage, analyse and collect data on key environmental issues. The centres are organized into networks involving approximately 90 specialized organizations across Europe (e.g., the Commission, the European Parliament, the Council of the EU and other EU institutions, participating EU Member States, a number of $\mathrm{NGOs}^{23}$, the scientific and academic community, business organizations and companies). The public is also among the most important target groups. The EEA thus seeks to provide the public with a better understanding of the importance of environmental and climate change issues, including the recent impact of GMOs on humans, animals, plants, and the environment (European Environment Agency, 2019).

The EEA publishes reports every five years on the state, trends, and prospects for the environment. These reports, which have been prepared since 1995, not only assess the state and forecasts of the European environment but also provide information on the implementation and development of EU policies. The 2020 report was published at a time when the companies and consumers are facing false information and news. This reality is also reflected in the report, which ensures transparency by making comprehensive references to not only scientific findings but also an improved approach to assessing and communicating aspects of quality, uncertainty and knowledge gaps. The report was also the subject of extensive peer

\footnotetext{
20 The EEA is the institution responsible for the development of Eionet and the coordination of its activities together with the national contact points in the EU Member States.

2128 EU Member States as well as Iceland, Liechtenstein, Norway, Switzerland, and Turkey.

22 Albania, Bosnia and Herzegovina, Montenegro, Northern Macedonia, Serbia and Kosovo (in accordance with UN Security Council Resolution 1244/99 and the International Court of Justice Opinion on the Declaration of Independence of Kosovo) (access, 15.8.2020).

${ }^{23}$ In Case T-33/16, the EU General Court ruled that the effects of GMOs on human or animal health fall within the field of the environment, so that non-governmental organizations under Regulation 1367/2006 require the EU institutions and bodies to, the right to participate in decisions on the placing on the market of foods containing GMOs. Moreover, the EU General Court annulled a decision by the Commission rejecting an NGO's request to review decisions authorizing the placing on the market of foods, food ingredients and feed containing GM soy (Court of Justice, 2019). The main purpose of the Aarhus Convention is thus to give rights to the public and to impose obligations on parties and public authorities regarding access to information and public participation and access to justice in environmental matters. As follows from the Council Decision of 17 February 2005 on the conclusion of the Aarhus Convention (2005/370), better public access to information and wider participation in proceedings are important means of raising public awareness of environmental issues and promoting better implementation and enforcement of environmental legislation.
} 
reviews by the EIONET Commission, the EEA Scientific Committee, and international experts. The 2020 report also contains topics that are important in terms of the impact of GMOs on the environment, and especially food production. Genetic diversity, adaptation of species and ecosystems to environmental change is/will be crucial for sufficient food production (European Environment Agency, 2019).

To preserve the most diverse biodiversity possible, especially the conservation of individual plant species, genetic diversity is imperative. The level of biodiversity is the variability within a species that allows organisms to better use, change, and adapt to environmental changes such as drought, moisture, and so on. Additionally, good plant and animal genetics are critically important for agriculture in general and, for the food supply specifically (Martinez \& Amri, 2008).

In addition to improving the quality of agricultural products, genetic diversity also supports regulation for ecosystems of processes such as pest and disease control. The vast geography of the EU Member States supports many varieties of crops and animal breeds. Unfortunately, many of the varieties of both crops and animals are classified as endangered. At least 130 previously known breeds of cattle are already classified as "extinct" (Hiemstra et. al., 2010; Food and Agriculture Organization, 2018).

Researcher Fu (2015) is convinced that gens diversity ${ }^{24}$ will be needed to increase crop yields. Lynch (2016) and Bohanec (2013) are also of the opinion that the greater the genetic diversity, the greater the possibility of resilience to future climate change.

The EEA report for 2020 contains topics that are so important for observing the impact of GMOs on the environment. One of the areas is the area of food production. Genetic diversity, adaptation of species and ecosystems to environmental change is / will be key to sufficient food production (European Environment Agency, 2019).

\footnotetext{
${ }^{24}$ The Genetic diversity is the total number of genetic characteristics in the genetic makeup of a species, it ranges widely from the number of species to differences within species and can be attributed to the span of survival for a species (Biological online dictionary, 2020).
} 
For example, plants and animals that are genetically tolerant to high temperatures or drought or resistant to pests and diseases are important in adapting to climate change, which requires a diverse genetic basis (Food Agriculture Organization, 2018).

\section{$5 \quad$ Conclusion}

Affixing GMO labels on products that are accessible to Slovenian consumers is certainly important. In practice, however, it is difficult to draw the line and determine which method of labelling is better or more effective for the consumer. The labelling of GMOs is a method that is legally determined, while the method of labelling without GMOs or with the label »Pridelano/proizvedeno brez, GSO - brez gensko spremenjenih organizmox« $(\mathrm{C}$ is not legally determined.

As there is no product in Slovenia that would be available to consumers for free sale and would contain the GMO label, this method cannot be compared with the method of labelling products with the GMO-free label. The key topic in Slovenia is that the GMO-free label is increasingly used on products on the market. The GMOfree label is not required by law. Products containing the GMO-free label or "Pridelano/proizvedeno brez GSO - brez gensko spremenjenih organizmov« $\mathcal{C}$ are hindered on the market by all other products showing that they have no "unfair competition." 25 Products intended for consumers in Slovenia that do not have the label without GMOs or »Pridelano/proizvedeno brez, GSO - brez gensko spremenjenih organizmov«(C) therefore do not represent products that could contain GMOs, but products on the market that comply with applicable regulations are safe for consumers.

My opinion is that the labeling of GMO products in EU Member States does not pose any serious risks, as GMO-labeled products underwent a comprehensive approval process before entering the market. However, non-GMO products are more dangerous for the consumer from the point of view of legal certainty, as the authorization procedure for such products has not been tested.

\footnotetext{
${ }^{25}$ Article 63a of ZPOmK-1 stipulates that unfair competition is the actions of companies in entering the market, which is contrary to good business practice and which determines or even causes damage to other companies.
} 
According to Zilberman et al. (2018), mandatory labeling of GMOs on products is not only inefficient but also unfair. The authors thus resist a situation that leads to a misperception of genetically modified foods, as labeling is a misleading opinion, which exacerbates the existence of the concept of GMOs. Moreover, according to these authors, the mandatory labeling of products is ill-advised since this approach will only serve to perpetuate a persistent negative belief held by some about GMOs and will limit such products' potential benefits to both human well-being and a healthier, more sustainable environment.

In recent years, EU legislation regarding genetically modified crops has come under severe criticism, primarily on the bases that legislation in this area is inconsistent, disproportionate, scientifically outdated, and unclear in scope. In 2017, for example, Zetterberg and Edvardsson Björnberg analyzed EU legislation on GMOs utilizing five criteria: legal safety, non-discrimination, proportionality, scientific flexibility, and the inclusion of non-verbal aspects. They concluded that the European regulatory framework for GMOs does not currently meet the criteria of legal certainty, non-discrimination, and scientific flexibility. These researchers also suggested two ways to reform existing legislation that will not only better meet the principles and criteria of legal certainty, non-discrimination, and scientific flexibility, but also address security concerns. The two suggested reforms are: a new risk assessment protocol and new crop legislation based on sustainability criteria. The new risk assessment protocol would employ more flexible rules than those currently in existence. These malleable rules would be adaptable in the future for the development of risk assessments for different groups of GMOs. This kind of flexibility is preferable to the current one-size-fits-all risk assessment approach. This is a legal solution that, to some extent, promotes the principle of non-discrimination, as it serves to relieve investigative burdens on low-risk genetically modified varieties. The second reform, new crop legislation based on sustainability criteria, would abandon the current "double path" and replace it with new crop legislation based on sustainability criteria applicable to all varieties, regardless of the cultivation methods used. Instead of focusing on whether the crop was developed by genetic modification or conventional cultivation methods, the proposed legislation would deviate from the values that are key to achieving sustainable development in plant breeding. This is a solution in line with the principle of non-discrimination; however, it presents a completely different regulatory logic, as the primary goal of such 
legislation would no longer be merely to avoid risk and harm, but also to achieve foreign sustainability goals (Zetterberg and Edvardsson Björnberg, 2017).

\section{Acts, Regulations and Court Decisions}

Act on Co-existence of Genetically Modified Plants with Other Agricultural Plants/Zakon o soobstoju gensko spremenjenih rastlin z ostalimi kmetijskimi rastlinami - ZSGSROKR, Official Gazette of RS, No. 41/09 w/amendments.

Council Regulation (EEC) No 1210/90 of 7 May 1990 on the establishment of the European Environment Agency and the European Environment Information and Observation Network, Official Journal L 120, 11/05/1990.

Court of Justice of the EU, Case C-528/16, French Agricultural Association and French associations against the French Minister for Agriculture and the French Prime Minister, ECLI: ECLI: EU: C: 2018: 583.

Court of Justice of the EU/Sodišče Evropske unije (2019) Letno poročilo 2018, Letni pregled (online), retrieved from: https://curia.europa.eu/jcms/upload/docs/application/pdf/201906/20190650_ra_pan_sl_2019-06-06_09-48-23_42.pdf (20 September 2020).

Decree on the implementation of the Regulation (EC) on genetically modified food and feed, and of the Regulation (EC) concerning the traceability and labelling of genetically modified organisms and the traceability of food and feed products produced from genetically modified organisms/Uredba o izvajanju Uredbe (ES) o gensko spremenjenih živilih in krmi in Uredbe (ES) o sledljivosti in označevanju gensko spremenjenih organizmov ter sledljivosti živil in krme, izdelanih iz gensko spremenjenih organizmov, Official Gazette of RS, No. 84/05 w/amendments.

Directive 2001/18/EC of the European Parliament and of the Council of 12 March 2001 on the deliberate release into the environment of genetically modified organisms and repealing Council Directive 90/220/EEC - Commission Declaration, Official Journal L 106, 17/04/2001 w/amendments.

Management of Genetically Modified Organisms Act/Zakon o ravnanju z gensko spremenjenimi organizmi - ZRGSO, Official Gazette of RS, No. 23/05 w/amendments.

Nature Conservation Act/Zakon o ohranjanju narave - ZON, Official Gazette of RS, No. 96/04 $\mathrm{w} /$ amendments.

Prevention of Restriction of Competition Act/Zakon o preprečevanju omejevanja konkurence ZPOmK-1, Official Gazette of RS, No. 66/08 w/amendments.

Regulation (EC) No 178/2002 of the European Parliament and of the Council of 28 January 2002 laying down the general principles and requirements of food law, establishing the European Food Safety Authority and laying down procedures in matters of food safety, Official Journal $L$ $31,1 / 02 / 2002$.

Regulation (EC) No 1829/2003 of the European Parliament and of the Council of 22 September 2003 on genetically modified food and feed, Official Journal L 268, 18/10/2003.

Regulation (EC) No 1830/2003 of the European Parliament and of the Council of 22 September 2003 concerning the traceability and labelling of genetically modified organisms and the traceability of food and feed products produced from genetically modified organisms and amending Directive 2001/18/EC, Official Journal L 268, 18/10/2003.

Regulation (EC) No 401/2009 of the European Parliament and of the Council of 23 April 2009 on the European Environment Agency and the European Environment Information and Observation Network, Official Journal L 126, 21/05/2009.

Regulation (EU) 2020/1043 of the European Parliament and of the Council of 15 July 2020 on the conduct of clinical trials with and supply of medicinal products for human use containing or 
consisting of genetically modified organisms intended to treat or prevent coronavirus disease (COVID-19), Official Journal L 231, 17/07/2020.

\section{References}

Arbeitsgemeinschaft für Gentechnik-frei erzeugte Lebensmittel (2020) The Quality Label (online), retrieved from: http://www.gentechnikfrei.at/was-heisst-gentechnik-frei (10 August 2020).

BioNewsServices (2021) Zolgensma (online), retrieved from: https://smanewstoday.com/zolgensma/ (22 March 2021).

Biological online dictionary (2020) Genetic diversity (online), retrieved from: https://www.biologyonline.com/dictionary/genetic-diversity.

Bohanec, B. (2013) Dr. Bohanec answers the most common questions and claims related to GMOs,

Biotechnology, opinions, science [e-newspaper], retrieved from: https://metinalista.si/dr-bohanecodgovarja-na-najpogostejsa-vprasanja-in-trditve-povezana -z-gso (22 March 2021).

Buiatti, M., Christou, P. \& Pastore, G. (2013) The application of GMOs in agriculture and in food production for a better nutrition: two different scientific points of view, Genes \& Nutrition, 8(3), pp. 255-270, doi: 10.1007/s12263-012-0316-4.

Burea veritas (2021) Donan Soja (online), retrieved from: https://www.bureauveritas.si/certificiranje/donau-soja (28 January 2021).

European Commission/Evropska komisija (2020a) Strategija ,od vil do vilic"za pravičen, zdrav in okolju prijazen prehranski sistem (online), retrieved from: https://eur-lex.europa.eu/legalcontent/SL/TXT/?qid=1590404602495\&uri=CELEX\%3A52020DC0381 (21 January 2021).

European Commission/Evropska komisija (2020b) Mednarodno sodelovanje na podroc̆ju zdravil (online), retrieved from: https://ec.europa.eu/health/international_cooperation/pharmaceuticals_sl (10.8.2020).

European Commission/Evropska komisija (2020c) Resne in kronicne bolezni (online), retrieved from: https://ec.europa.eu/health/non_communicable_diseases/overview_sl (16 December 2020).

European Environment Agency (2019) The European environment — state and outlook. 2020, Knowledge for transition to a sustainable Europe (Poročilo za leto 2020 - SOER 2020), retrieved from: https://www.eea.europa.eu/publications/soer-2020 (10 August 2020).

European Food Safety Authority (2020) GMO (online), retrieved from: https://www.efsa.europa.eu/en/topics/topic/gmo (23 July 2020).

European Medicines Agency (2016) Evropski regulativni sistem za zdravila - Uskelajen pristop k regulaciji zdravil po vsej Evropski uniji (online), retrieved from: https://www.ema.europa.eu/en/documents/leaflet/european-regulatory-system-medicineseuropean-medicines-agency-consistent-approach-medicines_sl.pdf (29 September 2020).

European Medicines Agency (2020) European Medicines Agency (online), retrieved from: https://www.ema.europa.eu/en/about-us/legal-notice\#disclaimer-section (10 August 2020).

Food and Agriculture Organization (2018) Domestic Animal Diversity Information System (D AD-IS)', Food and Agriculture Organization of the United Nations (online), retrieved from: http://www.fao.org/dad-is/en (26 September 2020).

Fu, Y. (2015) Understanding crop genetic diversity under modern plant breeding, Theoretical and Applied Genetics, 128, pp. 2131-2142, doi: 10.1007/s00122-015-2585-y.

Health Inspectorate of the Republic of Slovenia/Zdravstveni inšpektorat Republike Slovenije, Poročilo o delu za leto 2016, 2017, 2018 (online), retrieved from: https://www.gov.si/drzavniorgani/organi-v-sestavi/zdravstveni-inspektorat/o-inspektoratu/ (29 January 2021).

Hiemstra, S. J., Mäkit-Tanila, A., Gandini, G. \& Hass de, Y. (2010) Local cattle breeds in Europe: development of policies and strategies for self-sustaining breeds, Wageningen Academic Publishers, (online), retrieved from: https://www.wageningenacademic.com/doi/book/10.3920/978-908686-697-7 (29 September 2020). 
Hilbeck, A., Meyer, H., Wynne, B., \& Millstone, E. (2020) GMO regulations and their interpretation: how EFSA's guidance on risk assessments of GMOs is bound to fail, Environmental Sciences Europe, 32, 54, doi: 10.1186/s12302-020-00325-6.

Institute for Control and Certification University of Maribor/Inštitut za control in certificiranje Univerza v Mariboru (2020) O standardu »Pridelano/proizvedeno brez GSO - brez gensko spremenjenih organizmove (online), retrieved from: https://www.ikc-um.si/ikc-um/zasebnistandard/standard-brez-gso/ (10 August 2020).

Koch, B. A. (2010) Damage Caused by GMO-s: Comparative Analysis, In: Koch, B. (ed.) Damage caused by genetically modified organisms (Berlin: De Gruyter), pp. XXVII, str. 882-892.

Krimsky, S. (2019) GMOs Decoded A Skeptic's View of Genetically Modified Foods (Cambridge, Massachusetts: MIT Press).

Launis, V. (2008) The Scope and Importance of Genetic Democracy, In: Launis, V. \& J Räikkä, J. (ed.) Genetic democracy: philosophical perspectives (Springer), retrieved from: https://www.springer.com/gp/book/9781402062056 (26 September 2020).

Lynch, A. J. (2016) Why is genetic diversity important? (online), retrieved from: https://www.usgs.gov/center-news/why-genetic-diversity-important (26 September 2020).

Martínez, A., \& Amri, A. (2008) Managing Plant Genetic Resources in the Agro-ecosystem: Global Change, Cropassociated Biodiversity and Ecosystem Services (online), retrieved from: http://www.fao.org/fileadmin/templates/agphome/documents/PGR/SoW2/AgroEcosystem_Thematic_Study.pdf (21 January 2021).

Meško Kuralt, K. (2018) Pravica do zdravstvenega varstva v luči uporabe gensko spremenjenih organizmov, VII. Mednarodna doktorsko-raziskovalna konferenca (Ljubljana: Univerza na Primorskem: Evropska Pravna fakulteta), retrieved from: https://www.evropf.si/media/website/2013/04/Zbornik_VI-DR_konf_30052018.pdf (26 September 2020).

Ministry of Agriculture, Forestry and Food/ Ministrstva za kmetijstvo, gozdarstvo in prehrano (2018) Poročilo za leto 2017 (online), retrieved from: https://www.gov.si/assets/organi-vsestavi/IKGLR/LetnaPorocila/f258af442a/Porocilo_IRSKGLR_2017.pdf (22 January 2021).

Ministry of Agriculture, Forestry and Food/ Ministrstva za kmetijstvo, gozdarstvo in prehrano (2017) Poročllo za leto 2016 (online), retrieved from: https://www.gov.si/assets/organi-vsestavi/IKGLR/LetnaPorocila/46b4f874c8/Porocilo_IRSKGLR_2016.pdf (22 January 2021).

Ministry of Agriculture, Forestry and Food/ Ministrstva za kmetijstvo, gozdarstvo in prehrano (2016) Porocilo za leto 2015 (online), retrieved from: https://www.gov.si/assets/organi-vsestavi/IKGLR/LetnaPorocila/b42110ac94/Porocilo_IRSKGLR_2018.pdf (22 January 2021).

Ministry of Agriculture, Forestry and Food/ Ministrstvo za kmetijstvo, gozdarstvo in prehrano (2020) Inšpektorat Republike Sloveniji za kmetijstvo, gozdarstvo, lovstvo in ribistvo, Poročilo za leto 2019 (online), retrieved from: https://www.gov.si/assets/organi-v-sestavi/IKGLR/LetnaPorocila/Letnoporocilo-o-delu-IRSKGLR-2019.pdf (10 May 2020).

Ministry of the Environment and Spatial Planning/ Ministrstvo za okolje in prostor (2021) Letna porocila o delu Inšpektorata RS za okolje in prostor - IRSOP (online), retrieved from: https://podatki.gov.si/dataset/letna-porocila-o-delu-inspektorata-rs-okolje-in-prostor-irsop (22 January 2021).

Naso, M. F., Tomkowicz, B., Perry, W. L. 3rd. Strohl, W. R. (2017) Adeno-Associated Virus (AAV) as a Vector for Gene Therapy, BioDrugs: clinical immunotherapeutics, biopharmaceuticals and gene therapy, 31(4), pp. 317-334, doi: 10.1007/s40259-017-0234-5.

National Institute of Public Health/Nacionalni institut za javno zdravje (2020) Zdravstveno-vagojni centri/centri za keepitev zdravja (ZVCT), retrieved from: https://www.nijz.si/sl/podatki/zdravstvenovzgojni-centri-centri-za-krepitev-zdravja-zvct (25 July 2020). 
National institute of Biology/ Nacionalni inštitut za biologijo (2020) Vpeljava novih metod za določanje kolicine GSO v živilih, (online), retrieved from: https://www.nib.si/aktualno/novice/1293znanstveni-dosezek-vpeljava-novih-metod-za-dolocanje-kolicine-gso-v-zivilih $\quad(1$ August 2020).

Neuwirth, R. J., \& Svetlicinii, A. (2015) Law as a Social Medicine: Enhancing International Inter-regime Regulatory Coopetition as a Means for the Establishment of a Global Health Governance Framework, Journal of Legal Medicine, 36(3/4), pp. 330-366, doi: 10.1080/01947648.2016.1161570.

Séralini, G. E., Mesnage, R., Clair, E. \& Gress, S. (2011) Genetically modified crops safety assessments: present limits and possible improvements, Environmental Sciences Europe Bridging Science and Regulation at the Regional and European, 23(10), retrieved from: https://enveurope.springeropen.com/articles/10.1186/2190-4715-23-10 (26 September 2020).

Verband Lebensmittel ohne Gentechnik (2020) Profile (online), retrieved from: https://www.ohnegentechnik.org/index.php?id=1121 (10 August 2020).

Wasmer, M. (2019) Roads Forward for European GMO Policy-Uncertainties in Wake of ECJ Judgment Have to be Mitigated by Regulatory Reform, Frontiers in Bioengineering and Biotechnology, 7: 132, doi: 10.3389/fbioe.2019.00132.

World Health Organization (2020) Food, genetically modified, retrieved from: https://www.who.int/health-topics/food-genetically-modified\#tab=tab_1 (29 September 2020).

Zetterberg, C., Edvardsson, \& Björnberg, K. (2017) Time for a New EU Regulatory Framework for GM Crops?, Journal of Agricultural and Environmental Ethics, 30, pp. 325-347, doi: 10.1007/s10806-017-9664-9.

Zilberman, D., Holland, T. G., \& Trilnick, I. (2018) Agricultural GMOs-What We Know and Where Scientists Disagree, Sustainability, 10(5), 1514, doi: 10.3390/su10051514. 
